Environment, Biodiversity \& Soil Security
(EBSS)

\title{
Irrigation Scheduling and Its Impacts on Freesia-Water Productivity, Vegetative and Flowering Parameters under Greenhouse Cultivation
}

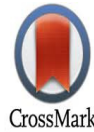

Ibrahim M. Abdel-Fattah ${ }^{1^{*}}$, Eman A. Attia ${ }^{2}$ and Ghada M. El-Banna ${ }^{2}$

${ }^{1}$ Soils, Water and Environment Res Inst., (SWERI), ARC., Egypt

${ }^{2}$ Ornamental Plants and Landscape Gardening Res. Dept., Hort. Res. Inst., ARC,

Egypt

\begin{abstract}
A POT experiment under greenhouse was conducted during 2017/18 and 2018/19 at Sakha Horticulture Research Station, North Nile Deltat of ind the impact of irrigation scheduling on freesia-water productivity, its yield, vegetative, flowering, cormsparameters and chlorophyll content. Four irrigation intervals of 3, 6, 9 and 12 days with four irrigation levels of 100 (control), 120,80, and 60\% cumulated pan evaporation (CPE) were tested. Results showed that irrigation scheduling significantly influenced the stated items. The mean seasonal irrigation water for the highest economical yield of fresh weight of spike was $12.58 \mathrm{~cm}$, while it was $14.05 \mathrm{~cm}$ for new corm under 9 days and $60 \%$ or 12 days and $80 \%$, respectively with mean value of $13.32 \mathrm{~cm}$. Regarding irrigation water productivity (IWP), the stated irrigation scheduling gave the highest IWP for spike $\left(0.7 \mathrm{~g} . \mathrm{cm}^{-1}\right)$ and new corm of $0.43 \mathrm{~g} . \mathrm{cm}^{-1}$. For freesia marketable yield of fresh weight of spike and new corm, maximum spike weight was obtained from 9 days and $60 \%$ and for fresh weight of new corm was obtained from 12 days and $80 \%$ CPE. By applying 12 days and $120 \%$ level, the highest values of plant height, number of leaves per plant and weight of fresh and dry vegetative growth were recorded, whereas, 3 days and $120 \%$ level gave the highest leaf area. Moreover, wateringeach 9 days and $80 \%$ CPEis the effective irrigation scheduling on flowering parameters. Mean while, 12 days and $60 \%$ is the proper irrigation scheduling for the highest total chlorophyll content.
\end{abstract}

Keywords: Freesia, Irrigation scheduling, Cumulated pan evaporation, Irrigation water productivity.

\section{Introduction}

Freesia (Freesia refracta cv. Aurara) is a cut flower crop and it was originated in South Africa. Freesia flowers come in different colors such as white, yellow, lavender, orange, golden, pink, red and violet. The Netherland has the largest production in the world with 280 cultivated hectares (Ali et al., 2011). They also stated that it is important to bring and acclimatize more and more freesia cultivars because of its aesthetic and economic value. The cut flowers grew in the world presently begun in the beginning of the $20^{\text {th }}$ century and it has become an important commercial activity in many developed and developing countries as well due to its high commercial values. The total production land for ornamental plants reached about 610,000 ha. It is known that there are more than 50 countries in the world performing cut flower growing. The most important producers of the European Union are Italy, Netherlands and Spain. The countries of the European produce $47 \%$ of the total cut flower production of the world (Aydinsakir et al., 2011).

Water is fast becoming a scarce resource in arid and semi-arid regions such as the Mediterranean basin (Gregory, 1984). There is high pressure on the ornamental floriculture industry to reduce water regimes and to produce

Corresponding author: hema_themanager@yahoo.com

Received:27 /04/ 2020 ; Accepted:4/06/2020

DOI: $10.21608 /$ jenvbs.2020.28824.1091

(C2020 National Information and Documentation Center (NIDOC) 
plants more efficiently in the face of government regulations on water use (Sanchez-Blanco et al. 2009). The irrigation scheduling, in particular the water amount and frequency in most ornamental nurseries, is based on arbitrary personal experience, which is rarely modified to match the crop water requirements (Grant et al. 2012). Water-saving irrigation management strategies are among the options available to horticultural growers to reduce water consumption and improve water use efficiency (WUE). Possible strategies include deficit irrigation (DI), regulated deficit irrigation, and partial root-zone drying. DI involves the application of water at a rate and volume lower than the evapotranspiration rate (ET) throughout the whole growth period and may be used in potted ornamental plants to improve plant quality by reducing excessive vigor and increasing WUE (Alvarez et al. 2009). In the last three decades, interest in DI has primarily centered on its potential to save water and/or to control excessive vegetative growth in fruit trees and vegetables (Costa et al., 2007). It's application to ornamental crops has received limited interest so far, because flowering ornamental plants are generally grown in pots, which provide a small water storage capacity in the root zone compared with open-field conditions. This small water-holding capacity makes it technically more difficult to apply DI without causing stress damage to the plants (Cameron et al., 2006).

In general, the impact of irrigation factor, particularly irrigation interval and irrigation amount under different cultivated crops showed a clear and significant effect on yield and water productivity. In other words, irrigation management of when to irrigate and how much water should be applied could be considered as a proper approach to sustain the soil and water resources in particular under arid and semi-arid regions (Saad and Abo-Koura, 2018; Darwesh 2018; Amer et al., 2019; Gewaily, 2019 and Amer et al., 2020).

Therefore, the aim of this study was to assess the effects of different irrigation scheduling (IS) on freesia cut flower crop grown in pots under greenhouse conditions. Specific goals were to find out: irrigation water productivity, impact of different irrigation scheduling on vegetative, flowering and yield characteristics of freesia.

\section{Materials and Methods}

A pot experiment was conducted under a plastic greenhouse during the two successive freesia growing seasons2017/2018 and 2018/2019 at Sakha Horticulture Research Station, Kafr ElSheikh Governorate, Egypt. The site represents the circumstances and conditions of North Nile Delta area with an elevation of $30^{\circ}-57^{\backslash}$ North, longitude $31^{\circ}-07$ East with altitude of about 6 meter above sea level. The study aimed to find out the response of freesia to different irrigation schedules, i.e. when to irrigate and how much water should be applied). Therefore, on $1^{\text {st }}$ October of each season, corms of 4-6 cm. circumferences (one corm per pot) were planted in $20 \mathrm{~cm}$ plastic pots at a depth of $2-3 \mathrm{~cm}$. Each pot has surface area of 314 $\mathrm{cm}^{2}$ and contained a mixture of clay and sand $(1: 1$, w/w) with $3.81 \mathrm{~kg}$. Some physical and chemical properties of the growing soil media are presented in Table 1 . In addition, some climatic elements during the growing seasons of the freesia crop are shown in Table 2.

TABLE 1. Soil characteristics of the pot experiment including clay and sandy soils

\begin{tabular}{|c|c|c|}
\hline Particle size distribution (\%) & Clayey soil & Sandy soil \\
\hline Clay & 60.00 & 2.60 \\
\hline Silt & 37.80 & 0.00 \\
\hline Sand & 2.20 & 97.40 \\
\hline Soil Texture & Clayey & Sandy \\
\hline pH & 7.94 & 7.70 \\
\hline $\mathbf{E C}, \mathrm{dS}^{\mathrm{m}}{ }^{-1}$ & 0.79 & 0.58 \\
\hline \multicolumn{3}{|l|}{ Soluble cations $\left(\mathrm{mmol} \mathrm{L}^{-1}\right)$} \\
\hline $\mathbf{C a}^{++}$ & 1.24 & 3.20 \\
\hline $\mathbf{M g}^{++}$ & 1.76 & 1.15 \\
\hline $\mathbf{N a}^{+}$ & 4.10 & 1.30 \\
\hline $\mathbf{K}^{+}$ & 0.80 & 0.15 \\
\hline \multicolumn{3}{|l|}{ Soluble anions $\left(\mathrm{mmol} \mathrm{L}^{-1}\right)$} \\
\hline $\mathrm{CO}_{3}^{--}$ & - & - \\
\hline $\mathrm{HCO}_{3}^{-}$ & 2.23 & 2.66 \\
\hline $\mathrm{Cl}^{-}$ & 4.00 & 1.36 \\
\hline $\mathrm{SO}_{4}^{-}$ & 1.57 & 1.78 \\
\hline
\end{tabular}

Env. Biodiv. Soil Security Vol. 4 (2020) 
TABLE 2. Climatological data of Sakha during the seasons (2017/18 and 2018/19)

\begin{tabular}{|c|c|c|c|c|c|}
\hline \multicolumn{6}{|c|}{$2017 / 2018$} \\
\hline Year & Month & $\mathbf{T}, \mathbf{C}^{\circ}$ & RH, \% & $\mathbf{U}_{2}, \mathbf{m ~ s e c}^{-1}$ & EP, mm day ${ }^{-1}$ \\
\hline \multirow{3}{*}{2017} & Oct & 26.4 & 67.9 & 0.85 & 3.26 \\
\hline & Nov. & 21.8 & 71.9 & 0.61 & 2.06 \\
\hline & Dec. & 20.0 & 76.5 & 0.50 & 1.47 \\
\hline \multirow{5}{*}{2018} & Jan. & 16.4 & 76.9 & 0.35 & 2.64 \\
\hline & Feb. & 18.0 & 75.1 & 0.37 & 2.74 \\
\hline & Mar. & 21.0 & 65.3 & 0.54 & 4.24 \\
\hline & Apr. & 23.9 & 62.4 & 0.85 & 5.32 \\
\hline & May & 27.6 & 59.7 & 1.10 & 6.34 \\
\hline \multicolumn{6}{|c|}{$2018 / 2019$} \\
\hline \multirow{3}{*}{2018} & Oct. & 25.1 & 66.1 & 0.66 & 3.24 \\
\hline & Nov. & 20.6 & 72.7 & 0.29 & 1.71 \\
\hline & Dec. & 16.0 & 76.4 & 0.33 & 1.16 \\
\hline \multirow{5}{*}{2019} & Jan. & 16.9 & 67.8 & 0.25 & 1.18 \\
\hline & Feb. & 18.1 & 72.6 & 0.41 & 2.21 \\
\hline & Mar. & 20.2 & 73.5 & 0.60 & 3.61 \\
\hline & Apr. & 24.6 & 60.12 & 0.60 & 4.67 \\
\hline & May & 30.2 & 54.4 & 1.09 & 8.56 \\
\hline
\end{tabular}

Four doses of NPK fertilizers (20:20:20) with a rate of $2 \mathrm{~g} \mathrm{pot}^{-1}$ were added. When plants started developing, the first dose was added at the rate of $2 \mathrm{~g}$ pot $^{-1}$ NPK fertilizer, and then three doses at monthly intervals were applied. Irrigation water was applied at planting with a rate of $750 \mathrm{ml} \mathrm{pot}^{-1}$, then corms were irrigated regularly for complete standing i.e. till the appearance of 4 leaves with total amount of $800 \mathrm{ml} \mathrm{pot}^{-1}$. In other words, each pot received irrigation water amounted with 1550 $\mathrm{ml}$ from planting till complete stand. Following to that, irrigation treatments were practiced.

\section{Irrigation treatments}

In both seasons of study, irrigation treatments were executed after one month following planting i.e. $1^{\text {st }}$ November as follows:

Main treatments: irrigation intervals

Treatment A: Irrigation every 3 days

Treatment B: irrigation every 6 days

Treatment C: irrigation every 9 days

Treatment D: irrigation every 12 days

Sub main treatments: irrigation levels

1- Irrigation with $120 \% \mathrm{CPE}$

2- Irrigation with $100 \% \mathrm{CPE}$ (control)

3- Irrigation with $80 \% \mathrm{CPE}$

4- $\quad$ Irrigation with $60 \% \mathrm{CPE}$

$\mathrm{CPE}=$ cumulative pan evaporation.

In both seasons, irrigation events were stopped in the last week of April when the leaves started yellowing. Furthermore, the new corms and cormels of freesia were picked after one month from the flowering. The amount of irrigation water was applied based on irrigation interval and evaporation from a class A pan (CAP) installed inside the greenhouse. The pan was located on a wooden support at a height of $15 \mathrm{~cm}$ above the soil surface and evaporation was recorded daily.

\section{Data collected}

Irrigation water

Under each irrigation interval, irrigation water was computed based on the cumulated pan evaporation (CPE) for each treatment.

\section{Irrigation water productivity (IWP)}

Irrigation water productivity (IWP) represents a useful parameter under the umbrella of cropwater functions which reflects the capability of irrigation water in producing the marketable yield as follows (Bos, 1980):

$$
\mathrm{IWP}=\mathrm{Y} / \mathrm{IW}
$$

As $: Y=$ marketable yield; $I W=$ applied irrigation water

\section{Vegetative characteristics}

Vegetative characteristics were determined during the vegetative period at the beginning of the first flower, the parameters were as follows: Plant height $(\mathrm{cm})$ Number of leaves plant ${ }^{-1}$; Leaf area $\left(\mathrm{cm}^{2}\right)$, Vegetative fresh and dry weights $\left(\operatorname{gpot}^{-1}\right)$.

It should be notified that leaf area per plant was estimated according to Metwally et al.(1998) which calculated for the fourth upper leaf as follows :

Leaf area $\left(\mathrm{cm}^{2}\right)=($ fresh weight of leaves /fresh weight of disks $) \times$ area per disk $\left(\mathrm{cm}^{2}\right)$, and then multiplied by number of leaves. 


\section{Flowering characteristics}

Flowering characteristics were determined during the flowering period after the opening of two flowers, the parameters were as follows :

- Flowering date, days, number of days from planting to the first bud opening

- Spike stem length, $\mathrm{cm}$, the length of the last flower between cutting point and the tip.

- Rachis length, cm, the length between the first and last flower, $\mathrm{cm}$

- Number of florets/ spike

- $\quad$ Spike fresh and dry weights, $g$

Corms and cormels productivity

Corms and cormels productivity were determined at the end of the growing season of freesia, the parameters were as follows: number of the produced cormels plant ${ }^{-1}$, fresh weight of the produced corms, g (corms yield), fresh weight of the produced cormels $(\mathrm{g})$,

\section{Chemical analysis}

Total chlorophyll (SPAD)

Total chlorophyll content was estimated using a portable chlorophyll meter SPAD-502 (KonicaMinolta, Osaka, Japan).

\section{Statistical design and analysis}

The experiment was carried out under split plot design in three replicates. The main plots represented irrigation intervals, while the subplots were allocated for irrigation levels. Analysis of variance was applied to the obtained results and the Duncan's multiple range test was used to compare the mean of treatments (Gomez and Gomez, 1984).

\section{Results and Discussion}

Irrigation water

An amount of $1551 \mathrm{ml}$ of irrigation water was applied to each cultivated pot during the 30 days following planting for complete standing of the corms, after that, different irrigation scheduling was implemented. Irrigation based on different irrigation scheduling i.e. irrigation intervals and irrigation levels which calculated based on the pan evaporation during each irrigation period. Seasonal values of water applied which started on $1^{\text {st }}$ October and ended on $27^{\text {th }}$ April i.e. one month before harvesting in the two seasons of study are presented in Table 3. It is clear from that table that the values of IW have the reverse trend of irrigation interval and vice versa with irrigation level. Meaningfully, the shortest irrigation interval, the highest in IW, while it has the same trend of irrigation levels. These results could be attributed to by decreasing irrigation intervals, more frequent watering events were came out compared to other longer irrigation intervals. In that regard, mean number of irrigations in the two seasons were 46, 23, 15 and 11 for irrigation intervals (3, 6, 9 and 12 days, respectively). On the contrary under each irrigation interval, increasing irrigation level resulted in high amount of irrigation water and vice versa.

The obtained results are emphasized those obtained by Khanam and Patra (2015) who stated that spike yield of Gladiolus was found maximum at $118 \mathrm{~mm}$ water use through low cost gravity drip system. Therefore, seasonal mean value of IW that gave the highest economical yield of freesia could be taken as $13.32 \mathrm{~cm}(1 \mathrm{~cm}$. irrigation water depth $\left.=42 \mathrm{~m}^{3} \mathrm{fad}^{-1}=100 \mathrm{~m}^{3} \mathrm{ha}^{-1}\right)$ which resulted from either 9 days and $60 \%$ or 12 days and $80 \%$ CPE as water level.

TABLE 3. Seasonal irrigation water (IW, $\left.\mathrm{L} \mathrm{pot}^{-1}\right)$ as affected by different irrigation intervals and irrigation levels for freesia in the two seasons

\begin{tabular}{cccccccc}
\hline Irrigation & Irrigation & \multicolumn{3}{c}{ Irrigation water $\left(\mathbf{L ~ p o t}^{\mathbf{1}}\right)$} & \multicolumn{3}{c}{ Irrigation water $(\mathbf{c m})$} \\
\cline { 2 - 7 } Intervals & Level & $\mathbf{1}^{\text {st }}$ season & $\mathbf{2}^{\text {nd }}$ season & Average & $\mathbf{1}^{\text {st }}$ season & $\mathbf{2}^{\text {nd }}$ season & Average \\
\hline & 1 & 59.40 & 59.10 & 59.12 & 18.82 & 18.82 & 18.83 \\
$\mathbf{A}$ & 2 & 67.87 & 67.90 & 67.89 & 21.61 & 21.62 & 21.62 \\
(3 days) & 3 & 50.41 & 50.39 & 50.40 & 16.05 & 16.05 & 16.05 \\
& 4 & 41.69 & 41.72 & 41.71 & 13.28 & 13.29 & 13.28 \\
& 1 & 59.14 & 59.10 & 59.12 & 18.83 & 18.82 & 18.83 \\
B & 2 & 67.87 & 67.92 & 67.90 & 21.61 & 21.63 & 21.62 \\
(6 days) & 3 & 50.42 & 50.30 & 50.36 & 16.05 & 16.02 & 16.04 \\
& 4 & 41.69 & 41.73 & 41.71 & 13.28 & 13.29 & 13.29 \\
C & 1 & 56.26 & 56.20 & 56.23 & 17.92 & 17.90 & 17.91 \\
(9 days) & 2 & 61.41 & 64.43 & 64.43 & 20.51 & 20.52 & 20.52 \\
& 3 & 48.11 & 48.22 & 48.17 & 15.32 & 15.36 & 15.34 \\
& 4 & 39.96 & 39.00 & 39.48 & 12.73 & 12.42 & 12.58 \\
D & 1 & 51.24 & 51.20 & 51.22 & 16.32 & 16.31 & 16.31 \\
(12 days) & 2 & 58.39 & 58.42 & 58.41 & 18.60 & 18.61 & 18.61 \\
& 3 & 44.09 & 44.16 & 44.13 & 14.04 & 14.06 & 14.05 \\
& 4 & 36.94 & 36.90 & 36.92 & 11.76 & 11.75 & 11.76
\end{tabular}
of pot).

Env. Biodiv. Soil Security Vol. 4 (2020) 
Predicting air temperature and pan evaporation inside greenhouse

It is useful to predict both air temperature and pan evaporation inside the greenhouse (Tin and Ep in). In this regard two regression equations represent the values of Tin and Epin as affected with the corresponding values in the outdoor (Fig.
1 and 2). So, to determine the amount of irrigation water should be applied to the growing crops under the greenhouse conditions, it is useful to use such relationships. In other words more effort could be gained by predicting the evaporation inside the greenhouse and hence applied irrigation water could be determined.
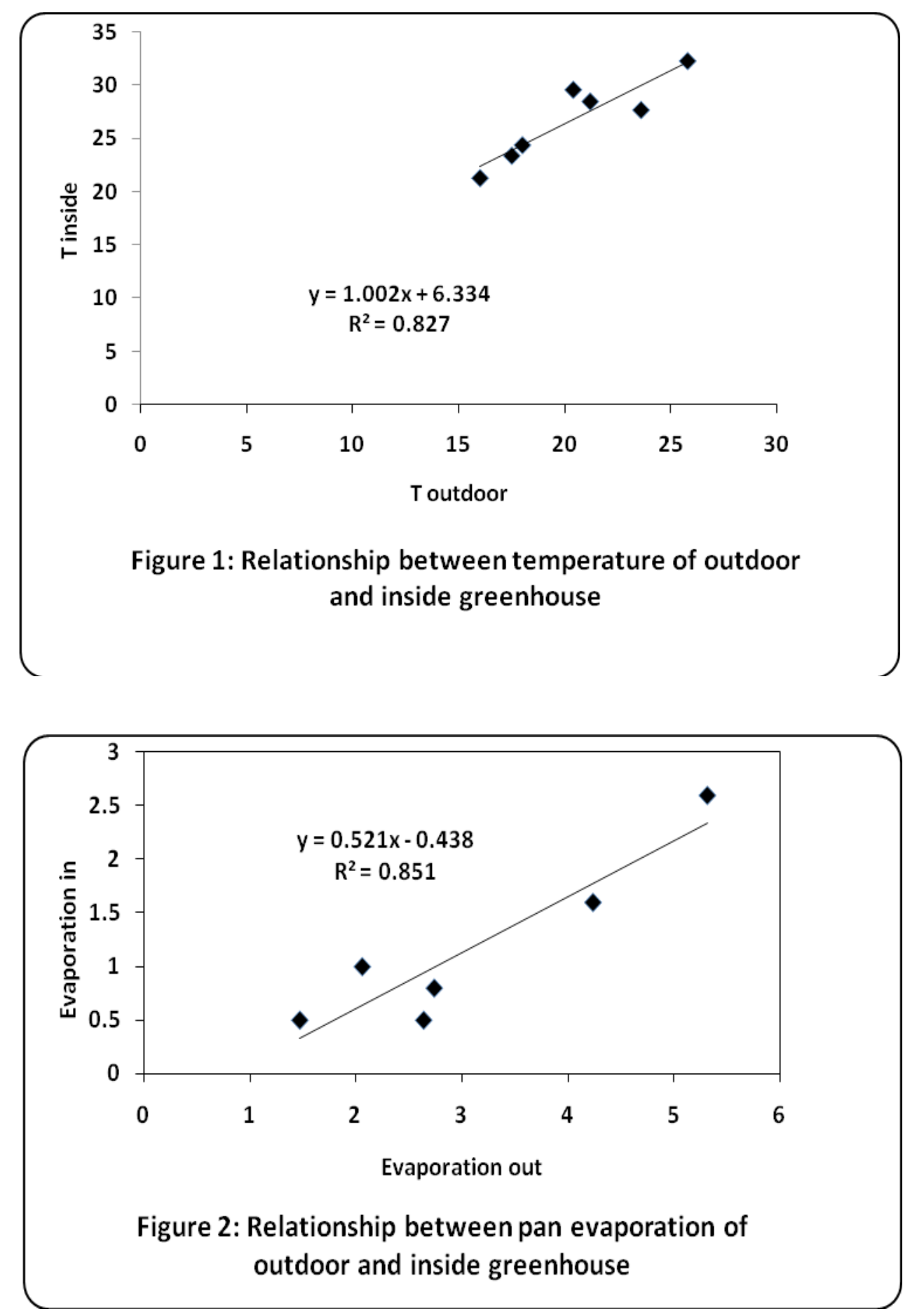
Irrigation water productivity

Irrigation water productivity as stated before reflects the capability of applied waterin producing the marketable yield. The relationship between yield of freesia flower and different applied irrigation water (IW) under each irrigation interval is presented in Table 4. Here with, for freesia, there are two main marketable yields; fresh spikes and fresh new corms. Regarding fresh weight of spike, it is clear from the data in Table 4 that the highest values of IWP in the two seasons are obtained from irrigating freesia each 9 days with $60 \% \mathrm{CPE}$ as water level (Trt.C4), with an average of 0.7 g.cm $\mathrm{cm}^{-1}$. On the contrary, the corresponding lowest values of IWP were recorded under 3 days and 100\% level (Trt.A1), with an average of $0.27 \mathrm{~g} / \mathrm{cm}$.

For fresh weight of new corm, data presented in that Table show that the highest values of IWP were achieved from 12 days interval and 60\% level (Trt.D4) in the first season and from Trt.C4 in the second season with 0.48 and $0.46 \mathrm{~g} . \mathrm{cm}^{-3}$, respectively. On the other hand, the lowest values of IWP were recorded under 3 days and $120 \%$ (Trt. A2) with an average of $0.09 \mathrm{~g} \cdot \mathrm{cm}^{-1}$. It should be notified that the lowest irrigation level of $60 \%$ is associated with the highest values of IWP because of irrigation water is the dominator of the equation of computing IWP. In other words, decreasing IW, higher values of IWP could be attained and vice versa. Therefore, as illustrated in Figure 1 , it is clear that $1 \mathrm{~cm}$. irrigation water produce maximum $0.7 \mathrm{~g}$ fresh spike and $0.43 \mathrm{~g}$ fresh new corm under the pot cultivation in greenhouse. The obtained results are in the same direction with that reported by Fereres and Soriano (2007) who stated that irrigation management in arid and semi-arid regions will shift from emphasizing production per unit area towards maximizing the production per unit of water consumed.

TABLE 4. Irrigation water productivity (IWP, $\mathrm{gcm}^{-1}$ ) as affected by different irrigation intervals and levels for freesia in the two seasons

\begin{tabular}{|c|c|c|c|c|c|c|c|}
\hline \multirow{2}{*}{$\begin{array}{l}\text { Irrigation } \\
\text { Intervals }\end{array}$} & \multirow{2}{*}{$\begin{array}{c}\text { Irrigation } \\
\text { Level }\end{array}$} & \multicolumn{3}{|c|}{ IWP, fresh weight of spike } & \multicolumn{3}{|c|}{ IWP, fresh weight of new corm } \\
\hline & & $1^{\text {st }}$ season & $2^{\text {nd }}$ season & Average & $1^{\text {st }}$ season & $2^{\text {nd }}$ season & Average \\
\hline & 1 & 0.24 & 0.29 & 0.27 & 0.16 & 0.11 & 0.14 \\
\hline $\mathbf{A}$ & 2 & 0.29 & 0.29 & 0.29 & 0.10 & 0.08 & 0.09 \\
\hline \multirow{3}{*}{ (3 days) } & 3 & 0.45 & 0.47 & 0.46 & 0.19 & 0.20 & 0.20 \\
\hline & 4 & 0.53 & 0.49 & 0.51 & 0.25 & 0.28 & 0.27 \\
\hline & 1 & 0.36 & 0.39 & 0.38 & 0.16 & 0.18 & 0.17 \\
\hline B & 2 & 0.24 & 0.32 & 0.28 & 0.12 & 0.11 & 0.12 \\
\hline \multirow{3}{*}{ (6 days) } & 3 & 0.47 & 0.51 & 0.49 & 0.25 & 0.24 & 0.25 \\
\hline & 4 & 0.54 & 0.59 & 0.57 & 0.34 & 0.35 & 0.35 \\
\hline & 1 & 0.44 & 0.45 & 0.45 & 0.19 & 0.19 & 0.19 \\
\hline $\mathrm{C}$ & 2 & 0.37 & 0.38 & 0.38 & 0.15 & 0.11 & 0.13 \\
\hline \multirow{3}{*}{ (9 days) } & 3 & 0.53 & 0.57 & 0.55 & 0.30 & 0.31 & 0.31 \\
\hline & 4 & 0.65 & 0.74 & 0.70 & 0.37 & 0.46 & 0.42 \\
\hline & 1 & 0.46 & 0.48 & 0.47 & 0.22 & 0.22 & 0.22 \\
\hline D & 2 & 0.43 & 0.41 & 0.42 & 0.19 & 0.19 & 0.19 \\
\hline \multirow{2}{*}{ (12 days) } & 3 & 0.51 & 0.51 & 0.51 & 0.40 & 0.40 & 0.40 \\
\hline & 4 & 0.57 & 0.60 & 0.59 & 0.48 & 0.38 & 0.43 \\
\hline
\end{tabular}

1-(100\% CPE), 2-(120\% CPE), 3-(80\% CPE), 4-(60\% CPE). CPE= Cumulative pan evaporation

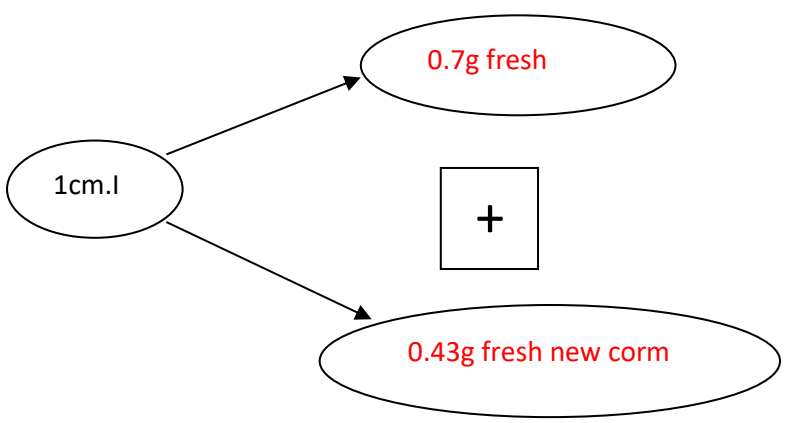

Fig. 3. Productivity of $1 \mathrm{~cm}$ IW of fresh weight of spike and new cormvegetative parameters.

Env. Biodiv. Soil Security Vol. 4 (2020) 


\section{Plant height}

As shown in Table 5, it is clear that plant height of freesia is highly significant affected with both irrigation intervals and levels, i.e. irrigation scheduling. The highest plant height 47.67 and $53.67 \mathrm{~cm}$ were recorded under irrigation interval of 12 days and 120\% water level (Trt.D2) in the two seasons, respectively. On the other hand, the lowest plant height values of 28.50 and 29.67 $\mathrm{cm}$ were recorded under 6 days $+100 \% \mathrm{CPE}$ and 9 days $+60 \% \mathrm{CPE}$ in the first and second season, respectively. So, to achieve the highest plant height of freesia cultivated under protected greenhouses, 12 days as irrigation interval along with $120 \%$ CPE as irrigation level (Trt.D2) could be executed.

\section{Number of leaves/plant}

It is obvious from data present in Table 5, that irrigation scheduling has a significant effect on number of leaves/plant. Where as, either different irrigation intervals or levels has no individualimpact on that trait. The highest values 10.67 and 10.00 leaves /plant were recorded under 3 days, $60 \%$ water level (Trt.A4) or 12 days and $120 \%$ (Trt.D2) in the first and second season, respectively. So, the highest number of leaves/ plant was obtained under 3 days $+60 \%$ (Trt.A4) or 12 days $+120 \%$ (Trt.D2) i.e. by decreasing both irrigation interval and level or increasing both of them.

\section{Leaf area}

Irrigation scheduling has a significant effect on that parameter as shown in Table 5. The highest leaf area values 15.89 and $19.83 \mathrm{~cm} 2$ for freesia plant were recorded under 3 days irrigation interval and 100\% irrigation level (Trt.A1) in the two seasons. Therefore, to attain the highest leaf area for freesia under the protected greenhouse pots cultivation, frequent irrigation interval of 3 days with $120 \%$ CPE as irrigation level (Trt.A2) could be practiced.

\section{Fresh and dry weight of vegetative growth}

Results of fresh weight as present in Table 5, show significant difference between treatments due to different irrigation scheduling. The highest values 11.27 and $11.50 \mathrm{~g}$ were obtained from irrigation interval 12 days with 120\% irrigation level (Trt.D2) in the two seasons. For irrigation level factor, it is cleared that $120 \%$ followed by $80 \%$ has the highest rank in the two seasons, while 12 days irrigation interval is the most suitable in connection with that trait of fresh weight of vegetative growth. Regarding dry weight of vegetative growth, it is clear from Table 5, that irrigation scheduling has a significant effect on that parameter. The highest values 3.50 and 3.17 $\mathrm{g}$ were recorded under 3 days and $60 \%$ irrigation level (Trt.A4). For the effect of irrigation level, it is clear that $80 \%$ has the first rank in the two seasons. Further more, 3 days has the highest rank in the first season and nodifference among the investigated irrigation intervals in the second season.

The obtained findings are in the same line with that stated by Lin et al. (2011) who reported that optimizing water management is an important step in order to determine the effects of water on the growth period of ornamental plants as well as their visual quality. Moreover, Bazaraa et al. (2012) pointed out that all growth parameters of Gladiolus cv. Novalux were progressively decreased by prolonging irrigation intervals, such as plant height, spike stem length and rachis length. So, to attain the highest fresh and dry weights of vegetative growth, 12 days as irrigation interval and $120 \%$ CPE as irrigation level could be implemented. Therefore, by applying 12 days and $120 \%$ level, the highest values of plant height, number of leaves per plant and fresh and dry weights of leaves were recorded. Meanwhile, 3 days irrigation interval and $120 \%$ level gave the highest leaf area of freesia.

\section{Flowering characteristics \\ Flowering date}

The flowering date significantly affected with different irrigation scheduling (Table 6). The longer duration 135 and 136 days after planting (DAP) were recorded under 6 days and 120\% level (Trt.B2), while the earliest days 101.67 and 100.33 are recorded under 3 days and $80 \%$ level in the two seasons, respectively.

\section{Spike length}

Data obtained in Table 6, revealed that there is a significant effect of irrigation scheduling on spike lengthin the two seasons, the longestspikes 12.37 and $13.70 \mathrm{~cm}$ were recorded under 3 days and $80 \%$ irrigation level (Trt.A3), while the shortest 8.83 and $8.50 \mathrm{~cm}$ were registered under the treatment A1 of 3 days and 100\% (control). Irrigation level of $80 \%$ has the highest effect in the two seasons, while there was no effect for different irrigation intervals on that parameter. In other words, irrigation level is the most effective factor on spike length. 


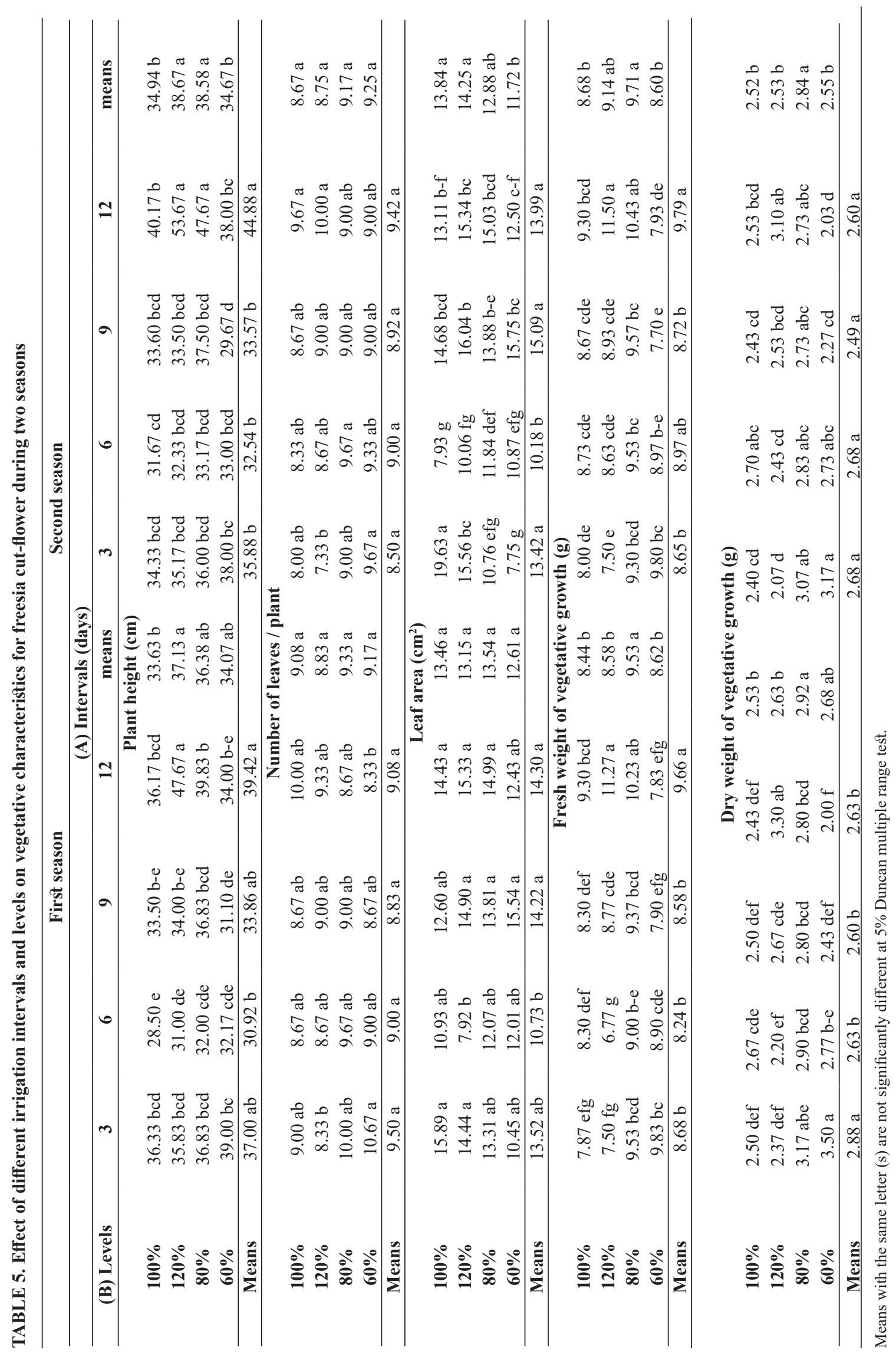

Env. Biodiv. Soil Security Vol. 4 (2020) 


\section{Rachis length (cm)}

Datain Table 6, showed a significant effect of irrigation scheduling on rachis length in the two seasons. In this regard, the longest rachis 7.93 $\mathrm{cm}$ was recorded in the first season under 6 days and $80 \%$ level (Trt.B3). In the second season, the highest value $7.33 \mathrm{~cm}$ was achieved undereither 12 days and $120 \%$ (Trt.D2) or 3 days and $80 \%$ (Trt. A3). On the contrary, the shortest values 4.50 and $4.97 \mathrm{~cm}$ were resulted under 3 days and $100 \%$ (Trt.A1) in the two seasons, respectively. Irrigation with $80 \%$ is the most effective level on that parameter in the first season, while irrigation with either 80 or $60 \%$ has the same effect in the second season. In connection with the impact of irrigation interval, watering each 6 days has the highest value in the first season and no difference among irrigation intervals in the second season.

\section{Number of florets/spike}

As shown in Table 6, it is cleared that irrigation scheduling has a significant effect on that parameter. In the first season, the highest value 7.67 was recorded under different irrigation intervals and levels; 3days and 60\% (Trt.A4), 6 days and 80\% (Trt.B3) and 12 days and 120\% (Trt.D2). In the second season, the highest value 8.00 was obtained under 12 days and $120 \%$ (Trt. D2). On the contrary, the lowest values 4.67 and 5.00 were recorded under 3 days and $100 \%$ water level (Trt.A1) in the two seasons, respectively. For irrigation level factor, the highest values were obtained under either 80 or $60 \%$ in the two seasons. Moreover, in the two seasons, no significant effect of the tested irrigation intervals on that parameter. The obtained results are in harmony with that obtained by Taylor et al. (2008), who reported that the maximum flower yield and the best quality of carnations were obtained when the soil moisture tension was kept at $45 \mathrm{kPa}$. Therefore, number of florets /spike is mainly affected with the water level i.e. the amount of applied irrigation water. The most effective irrigation level is either $80 \%$ or $60 \% \mathrm{CPE}$.

\section{Fresh and dry weight of spike}

The impact of irrigation scheduling on fresh and dry weight of spike is significant as shown in Table 6. In the two seasons, the highest values 8.30 and $9.13 \mathrm{~g}$ as fresh weight, while the corresponding values 2.57 and 2.62 gas dry weight were obtained under 9 days and 60\% irrigation level (Trt.C4). On the other hand, in the two seasons, the lowest values 4.47 and 5.43 $\mathrm{g}$ as fresh weight were resulted under 3 days and 100\% irrigation level (Trt.A1). However, for dry weight of spike, the lowest values 1.37 and 1.60 $\mathrm{g}$ were recorded under 3 days and 100\% (Trt.A1) in the first season and 3 days and 120\% (Trt.A2) in the second season, respectively. Regarding the impact of irrigation level, the highest values of fresh and dry weight were obtained under $80 \%$. The irrigation interval 9 followed by 12 days has the first rank for fresh and dry weight of spike. Therefore, irrigating freesia each 9 days with $80 \%$ CPE as water level produced the highest values of fresh and dry weight of spike. The obtained results are in the same direction with that found by Bazaraa et al. (2012) who concluded that by prolonging irrigation intervals of Gladiolus, number of flowers/spike, number of days to flowering and fresh weight of cut spike were decreased. So, irrigation scheduling has a significant effect on flowering characteristics of; flowering date, spike length, rachis length, number of florets/spike and fresh and dry weight of spike. In general, irrigation interval of 9 days with $80 \% \mathrm{CPE}$ as irrigation level is the most effective irrigation scheduling on flowering parameters.

\section{Corms and cormels productivity}

Fresh weight of new corm/pot

Irrigation scheduling of freesia has a clear significant effect on that economic product of new corms present in Table 7. In this regard, the highest values 5.60 and $5.68 \mathrm{~g}$ are recorded under 12 days and $80 \%$ level (Trt.D3) in the two seasons, respectively. For irrigation level, the highest rank of that parameter was visually under $60 \%$. Furthermore, irrigation interval of 12 days produced the highest value in the two seasons. Therefore, by implementing irrigation interval of 12 days with $80 \%$ or even $60 \%$ CPE as water level produced the highest weight of new corm.

\section{Number of cormels}

As present in Table 7, it is clear that irrigation scheduling has a significant effect on number of cormels for freesia flowers in the two seasons. In the first season, the highest number 6 was recorded three times; under 9 days and $60 \%$ level (Trt.C4), 12 days and 80\% (Trt.D3)and 12 days and $60 \%$ (Trt,D4), while in the second season, the highest number 6.33 was obtained under 12 days and $80 \%$ level (Trt.D3). Regarding the effect of irrigation level $60 \%$ has the highest value in the two seasons. Meanwhile, irrigation interval of 9 and 12 days produced the highest number of cormels in first and second season, respectively. Therefore, irrigation interval of 9 or 12 days accompanied with 80 or $60 \%$ CPE produced the highest number of cormels. 


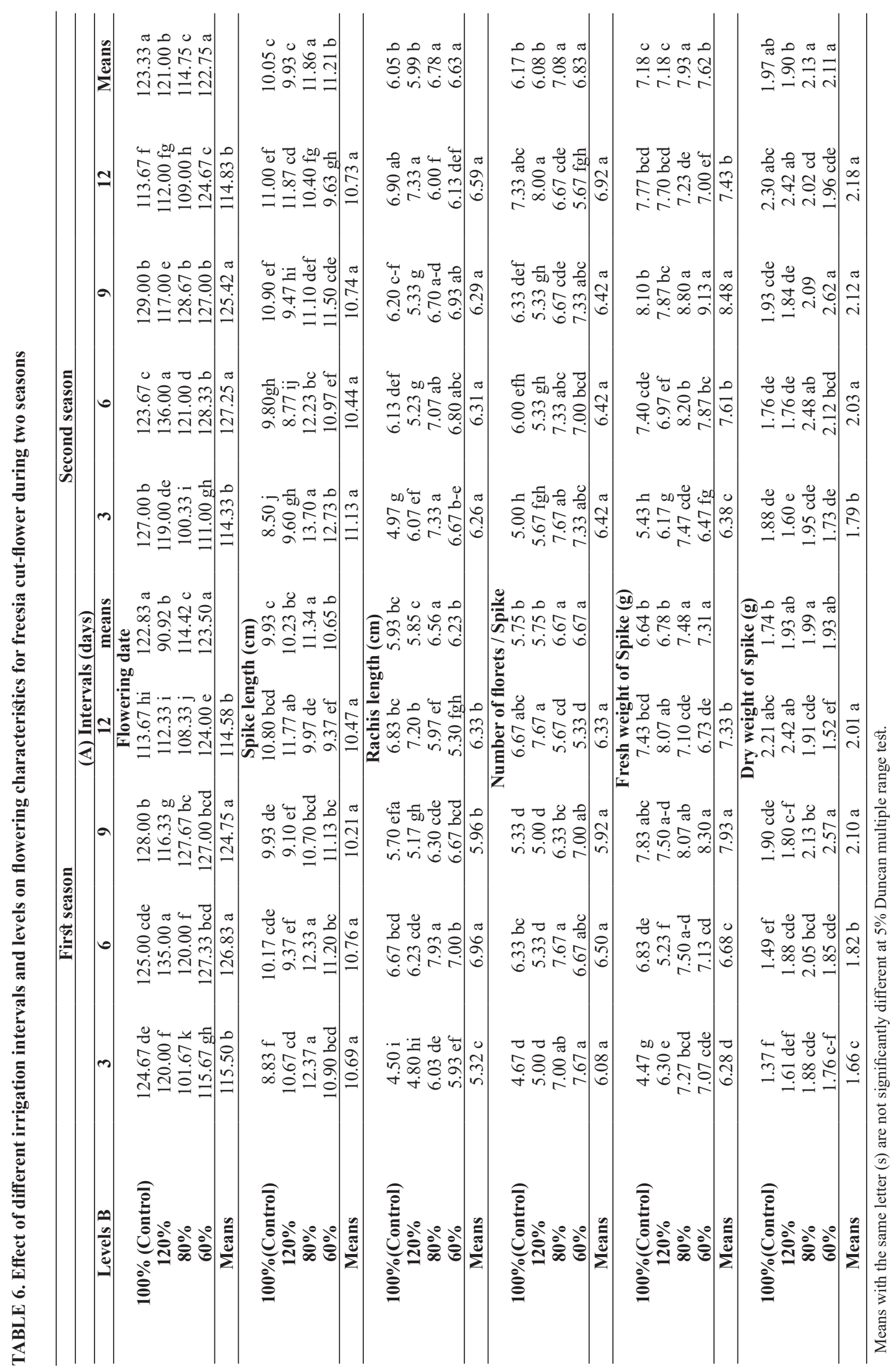

Env. Biodiv. Soil Security Vol. 4 (2020) 


\section{Fresh weight of cormels}

Irrigation scheduling has a pronounced significant effect on fresh weight of cormelsin the two seasons as figurate in Table 7 . The highest values 5.82 and $6.96 \mathrm{~g}$ are recorded respectively under 12 days and $80 \%$ level (Trt.D3) in the two seasons. On the other hand, the lowest values 2.98 and $2.25 \mathrm{~g}$ in the two seasons were respectively obtained under 3 days and 120\% (Trt.A2). The obtained results are in a good agreement with that reported by Youssef (2013) on gladiolus concluding that decreasing the amount of irrigation water i.e. irrigation with 80 or $60 \%$ of evapotran spiration $\left(\mathrm{ET}_{\mathrm{c}}\right.$ ) significantly decreased the number of cormels per plant, cormels fresh weight and diameter and weight of corm in comparison with $100 \% \mathrm{ET}_{\mathrm{c}}$. Moreover Bazaraa et al. (2012) stated that all corms and cormels parameters of Gladiolus were gradually increased by prolonging irrigation intervals. So, the highest values of fresh weight of cormels have the same trend with elongating irrigation interval and vice versa regarding irrigation level. Therefore, irrigating freesia each 12 days with $80 \% \mathrm{CPE}$ as water level produced the highest values of corm productivity and its attributes of number of cormels and fresh weight of cormels.

\section{Total chlorophyll}

Irrigation scheduling has a clear significant effect on total chlorophyll content of freesia flowers as show in Table 8 . The highest values 47.57 and 48.00 in the two seasons, respectively were recorded under 12 days interval and 60\% irrigation level (Trt.D4). On the contrary, the lowest values 35.90 and 36.30 were obtained in the two seasons, respectively under 3 days and 120\% irrigation level (Trt.A2). Meaningfully, the highest values of total chlorophyll were recorded under the less irrigation level and the longest irrigation interval. In other words, total chlorophyll content of freesia flowers was increased by increasing irrigation interval and decreasing the applied irrigation level. In Contrary, decreasing the amount of irrigation water from 1882 to 1129 $\mathrm{m}^{3}$. $\mathrm{fad}^{-1}(1 \mathrm{fad}=0.42 \mathrm{ha})$ on gladiolus caused significant reduction in both chlorophyll $a, b$ and chlorophyll $\mathrm{a}+\mathrm{b}$ (Youssef 2013). Therefore, in general, productivity of corms and cormels expressed with their items; fresh weight of new corm, number of cormels and fresh weight of cormels which considered as the main economic production of freesia flowers could have the same trend with elongating irrigation intervals and decreasing applied irrigation level. Moreover, total chlorophyll has the same direction with that of corms productivity.

\section{Conclusion}

The obtained results revealed that irrigation intervals and levels play an effective role on freesia grown in pots under plastic greenhouse regarding its attributes of vegetative, flowering and yield. Mean seasonal irrigation water that gives the highest values of economical yield of fresh weight of both spike and new corm was $13.32 \mathrm{~cm}$ recorded under 9 days $+60 \%$ or 12 days $+80 \%$, respectively. The stated irrigation scheduling gave also the highest values of irrigation water productivity of $0.7 \mathrm{~g}$ fresh spike and $0.43 \mathrm{~g}$ fresh weight of new corm'. Irrigation interval of 12 days with $120 \% \mathrm{CPE}$ as water level followed by 3 days and $60 \%$ had the highest values of vegetative characteristics except leaf area which was recorded under 3 days and 120\%. Irrigation interval of 9 days and $80 \% \mathrm{CPE}$ as irrigation level is the most effective irrigation scheduling on flowering parameters. The economical yield of freesia cut flower crop includes two main products of fresh weight of both spike and new corm. Irrigation interval of 9 days and $60 \%$ produced the highest fresh weight of spike, where as 12 days and $80 \%$ produced the highest weight of new corm. The highest total chlorophyll was determined under 12 days and $60 \%$. Therefore, it could be concluded that irrigating freesia cut flower each 12 days with $80 \%$ water level gave the highest yield as well as most of the studied parameters. That finding was obtained for pot cultivation with mixed soils of clay and sand (1:1). Irrigation amount for different irrigation intervals for freesia was computed based on pan evaporation under plastic greenhouse in North Nile Delta. Lastly but not last, further studies should be carried out to emphasize the role of irrigation on ornamental crops owing to achieve the goal of "produce more per less". 



Env. Biodiv. Soil Security Vol. 4 (2020) 


\section{References}

Ali, T., Khattak, A. M., Amin, N. U. and M. A. Khan (2011) Response of freesia cultivars to different growing media under peshawar conditions.Sarhad J. Agric. 27 (1).

Alvarez, S., Navarro, A., Banon, S. and M. J. SanchesBlanco (2009) Regulated deficit irrigation in potted Dianthus plants: Effects of severe and moderate water stress on growth and physiological responses. Sci. Hort. 122:579-585.

Amer, M.A and A.A. Koura (2018) Improvement of Sorghum (Sorghum bicolor l. Moench) Growth and Yield under Drought Stress by Inoculation with Bacillus cereus and Foliar Application of Potassium Silicate. Env. Biodiv. Soil Security. 2. 205 - 220

Amer,M.A; Aiad, M. Rashed,S.H. and H. El-Ramady (2019) Sustainable Irrigation and Fertilization Management of Successive Cultivated Sugar Beet and Cotton under Salt-affected SoilConditions.Env. Biodiv. Soil Security, 3, 227 - 239.

Amer, M.A., Gazia, E.A., Aboelsoud,H.M and S.H. Rashed (2020) Management of Irrigation Water and Organic Matter Application Contribution in Improving Some Soil Properties and Yields - Water Productivity of Sugar Beet and Cotton in Salt Affected Soil. Env. Biodiv. Soil Security, 4, 7 - 18.

Aydinsakir, K.,Tuzel, I. H. and D. Buyuktas (2011) The effects of different irrigation levels on flowering and flower quality of carnation (Dianthus caryophllus L.) irrigated by drip irrigation. African J. of Biotechnology, 10 (66),14826-14835.

Bazaraa, W. M., Abdel-Fattah Gehan, H. and A. Nabih (2012) Effect of soil media, biostimulants and fertilization on corms and cormlets production and chemical constituents of Gladiolus cv. Novalux. Egypt J. Hort., 39 (2): 105-120.

Bos, M. G. (1980) Irrigation efficiencies at crop production level. ICID, Bulletin, 29, 2: 189-260, New Delhi.

Cameron, R. W. F., Harrison-Murray, R. S., Atkinson, C. J. andH. L. Judd( 2006) Regulated deficit irrigation: A means to control growth in woody ornamentals. J. Hortic. Sci. Biotechnol. 81:435-443.

Costa, J. M.; Ortuno, M.F. and M. M. Chaves (2007) Deficit irrigation as a strategy to save water: Physiology and potential application in horticulture. J. Integr. Plant. Biol. 49, 1421-1434.

Darwesh, R.Kh. (2018) Water Productivity for Egyptian Clover as Affected by Different Irrigation Regimes and Cultivation Methods in The North Middle
Nile Delta Region. Env. Biodiv. Soil Security. 2, 193 -203 .

Fereres, E. and M.A. Soriano (2007) Deficit irrigation for reducing agricultural water use. J. Exp. Bot. 58, 147-159.

Gewaily, E. E. (2019) Influence of Arbuscular Mycorrhizal Fungi (AMF) Inoculation on the Performance of Sakha 107 Rice Cultivar under Different Irrigation Intervals. Env. Biodiv. Soil Security. 3, 119 - 129

Gomez, K.A. and A.A. Gomez (1984) Statistical procedures for agricultural research. An Int. Rice Res. Inst. Book. John Wiley and Sons, Inc. p. 680. New York, USA.

Grant, O. M., Davies, M. J., Longbottom, H. andR. Harrison-Murray (2012) Evapotranspiration of container ornamental shrubs: Modeling cropspecific factors for a diverse range of crops. Irrig. Sci. 3,1-12.

Gregory, P. G. (1984) Water availability and crop growth in arid regions. Outlook Agr. 13:208-215.

Khanam, R. and S. K. Patra (2015) Effect of gravity drip irrigation on growth, yield and water use efficiency of Gladiolus in lower Gangetic plain of west Bengal, India. Int. J. Ecosystem, 5 (3A): 132137.

Lin, I., Li, W., Shon, J., Luo, W.,Dai, J., Yin, X., Zhon, Y. and C. Zhao (2011) Modeling the effects of soil water potential on growth and quality of cut chrysanthemum (Chrysanthemum morifolium). Scientia Horticulturae, 130, 275-288.

Metwally, E. L., A. M. Hewedy, M. Hafez and M. A. Morsy (1998) Kafr EL-Sheikh-1 and Kaha-1 New cultivars of cowpea. J. Agric. Sci. Mansoura Univ., 23 (8): 3887-3897.

Sanchez-Blanco, M. J., Rodriguez, P., Morales, M. A., Ortuno, M. F. and A. Torrecillas (2009) Comparative growth and water relation of Cistus albidus and Cistus monspeliensis plants during water deficit conditions and recovery. Plant Sci. 162:107-113.

Taylor, R.D., Hill, J. and W.W. Grout (2008) Does irrigation regime affect the post-harvest quality and vase life of cut flower carnations (cv. Santorini) ActaHortic. 792: 663-668.

Youssef, E.A. (2013) Response of gladiolus plants to water regimes and improving quality agents under different irrigation systems in newly reclaimed soil. Ph.D. Thesis, Fac., Agri., Zagazig Univ., Egypt. 